\title{
The Lumumba University in Moscow: higher education for a Soviet-Third World alliance, $1960-91^{\dagger}$
}

\author{
Constantin Katsakioris \\ Bayreuth Academy of Advanced African Studies, Hugo-Rüdel-Str. 10, 95445 Bayreuth, Germany \\ Corresponding author. Email: konstantinos.katsakioris@uni-bayreuth.de
}

\begin{abstract}
Founded in Moscow in 1960 for students from Third World countries, the Peoples' Friendship University 'Patrice Lumumba' was the most important venture in international higher education during the Cold War and a flagship of Soviet internationalism. It aimed to educate a Soviet-friendly intelligentsia and foster a Soviet-Third World alliance. This article retraces the history of this school, often criticized for its Third World concept, recruitment, and training policies. It recalls the forgotten French initiative to create a university for the underdeveloped countries, situates Lumumba University in the global Cold War, and compares it with mainstream Soviet schools. Soon after its creation, Lumumba University underwent important changes, but departed from its initial educational concept. Consequently, arguments justifying the existence of a special university disappeared. Third World countries, moreover, never agreed with the university's concept. Despite its educational accomplishments, Lumumba University became the Achilles' heel of Soviet cultural policy.
\end{abstract}

Keywords: Cold War; education; Patrice Lumumba University; Soviet Union; Third World

As Asian and African countries made the transition to independence after the Second World War, the development of education and the training of their elites were widely recognized as indispensable preconditions for building prosperous nation-states. The specific link between education and development was steadily reinforced after the Second World War as various actors invested their hopes and interests in the achievement of these twin goals. The expansion of education was an integral part of the colonial development programmes implemented by the European empires after 1945. ${ }^{1}$ The United Nations Educational, Scientific, and Cultural Organization (UNESCO) considered its educational activity to be a contribution to both peace and development. Economists argued that investment in human capital promised higher returns than investment in fixed capital. ${ }^{2}$ At the 1961 Addis Ababa Conference of African States on the Development of Education in Africa, delegates stressed the centrality of education to 'economic and social development', committed themselves to its expansion, and appealed to foreign donors. ${ }^{3}$ The United States, the Soviet Union, and other actors subscribed to these views and provided substantial amounts of aid. 'In a sense, this period was the culmination of the Enlightenment promise for

${ }^{\dagger} \mathrm{I}$ am grateful to the anonymous reviewers for their remarks, to the Bundesministerium für Bildung und Forschung in Germany for its support, and to the Jordan Center for the Study of Russia at New York University, where this article was presented.

${ }^{1}$ Frederick Cooper, 'Writing the history of development', Journal of Modern European History, 8, 1, 2010, pp. 5-23.

${ }^{2}$ Charles Dorn and Kristen Ghodsee, 'The Cold War politicization of literacy: communism, UNESCO, and the World Bank', Diplomatic History, 36, 2, 2012, pp. 373-98.

${ }^{3}$ Conference of African States on the Development of Education in Africa: final report, Paris: UNESCO, 1961.

(C) Cambridge University Press 2019. This is an Open Access article, distributed under the terms of the Creative Commons AttributionNonCommercial-NoDerivatives licence (http://creativecommons.org/licenses/by-nc-nd/4.0/), which permits non-commercial re-use, distribution, and reproduction in any medium, provided the original work is unaltered and is properly cited. The written permission of Cambridge University Press must be obtained for commercial re-use or in order to create a derivative work. 
progress through education', Immanuel Wallerstein later recalled, adding that, 'In itself, this was a wonderful thing.' 4

These shared views notwithstanding, the Cold War cast a shadow over education policies. Responding to the resounding success of Cuba's 1961 literacy campaign, which had been hailed for simultaneously raising the political consciousness of peasant masses, Western officials in UNESCO and the World Bank advocated the relevance of 'functional literacy' and 'occupational education' to agricultural or industrial development purposes..$^{5}$ Educational planning became another highly politicized issue. The Soviets maintained that efficient educational planning should be part of comprehensive economic planning and provide for raising the overall educational and cultural level of workers. Responding to the sweeping Soviet approach, Americans promoted the idea that the 'right number' and kind of high-level workforce and skilled workers should be trained to produce useful goods and services with respect to each 'society's cultural identity'. 6

No other issue, however, was as politicized and as urgent for Third World countries as the training of students, who were expected to replace colonial administrators, teachers, or expatriate engineers. Seeing students as the new elites that would shape their countries' future, both East and West offered thousands of scholarships and made their training a priority. By the turn of the 1950s, international higher education epitomized the oft-cited 'battle for hearts and minds'. It was in this context that in February 1960, during a visit to Indonesia, the secretary general of the Communist Party of the Soviet Union (CPSU), Nikita Khrushchev, announced the foundation of the Peoples' Friendship University in Moscow, especially for students from Asia, Africa, and Latin America. Addressing 3,000 students at Jogjakarta University, Khrushchev affirmed that the Soviet government 'wished to help the [developing] countries to train their national workforce, engineers, agronomists, doctors, teachers, economists' and at the same time give a chance to 'many talented young people coming from poor families', who otherwise were 'deprived of the possibility of realizing their wish to study in the Soviet Union'. ' Candidates were soon invited to apply for the 600 places, and they did so in their thousands. ${ }^{8}$

This article revisits the history of the Peoples' Friendship University (Universitet Druzhby Narodov, henceforth 'UDN'), which constituted the single most important venture in international higher education during the Cold War. Rechristened 'Patrice Lumumba' in February 1961, after the assassinated Congolese leader, the school was also conceived as a powerful symbol of Moscow's solidarity with the Third World. UDN students who contributed to the school's publications expressed their gratitude to the USSR, as did many graduates, who still today revere their alma mater. ${ }^{9}$ Recent accounts by past professors celebrate the university's unique history and major accomplishments. ${ }^{10}$

On the opposite side, as soon as UDN opened its doors, it became the target of sharp reactions. The Togolese Michel Ayih, one of the first Africans to study in the USSR, who later 'defected' to West Germany, wrote that UDN had been created to isolate and indoctrinate African and Asian students. ${ }^{11}$ Encouraged by anti-communist activists in the West, other former students followed

\footnotetext{
${ }^{4}$ Immanuel Wallerstein, The essential Wallerstein, New York: The New Press, 2000, p. 416.

${ }^{5}$ Dorn and Ghodsee, 'The Cold War politicization of literacy'.

${ }^{6}$ Articles by Stanislav Strumilin, Frederick Harbison, and Ricardo Diez-Hochleitner, in Economic and social aspects of educational planning, Paris: UNESCO, 1964.

${ }^{7}$ Tamara Krasovitskaia, et al., eds., 'Vozvratit' domoi druzh'iami SSSR': obuchenie inostrantsev v Sovetskom Soiuze ('Return home as friends of the USSR': the training of foreigners in the Soviet Union), Moscow: Mezhdunarodnyi Fond Demokratiia, 2013, p. 605.

${ }^{8}$ Soviet officials announced that in 1960 UDN received 45,000 applications. An internal report, however, mentions 'more than 4,000 applications' in 1962: Russian State Archive of Social and Political History (Rossiiskii Gosudarstvennyi Arkhiv Sotsial'no-Politicheskoi Istorii; henceforth RGASPI), fond. 1, op. 46, d. 294, p. 105.

${ }^{9}$ Abigail Judge Kret, 'We unite with knowledge: the Peoples' Friendship University and Soviet education for the Third World', Comparative Studies of South Asia, Africa and the Middle East, 33, 2, 2013, pp. 239-56.

${ }^{10}$ Ludmila Ponomarenko and Elena Zueva, PFUR and Africa, Moscow: Peoples' Friendship University, 2009.

${ }^{11}$ Michel Ayih, Ein Afrikaner in Moskau, Cologne: Bertelsmann, 1961, p. 142.
} 
suit. The Liberian William Appleton even called the university a 'student trap'. ${ }^{12}$ In Moscow, such attacks provoked embarrassment. In London, however, as early as November 1962, an official at the Foreign Office could not help but rejoice in Soviet troubles, concluding in his confidential report: 'The establishment of a kind of African ghetto in the form of the Lumumba University has clearly been an error.'13

In subsequent years Lumumba University continued to be depicted as a centre of MarxistLeninist indoctrination, or as a breeding ground for revolutionaries and terrorists. Revelations that Rohana Wijeweera, the leader of the Popular Liberation Front who, in 1971, led a revolution in Sri Lanka, and Ilich Ramírez Sanchez, the Venezuelan terrorist known as Carlos the Jackal, had sat at Lumumba's desks did not serve the school's reputation well. ${ }^{14}$ In the 1980s, following the shock of the Iranian Revolution, the CIA compared UDN to Qom, the religious school where radical clerics were educated. ${ }^{15}$ Post-Cold War representations reproduced these images. The school appears in documentary films that relate the life of Carlos, and is recalled by the Chilean novelist Luis Sepúlveda, himself a former student in the USSR, as a destination for Latin American communists, although it was considered inferior to the prestigious Moscow State University. ${ }^{16}$

Contrary to these accounts, this article delves into UDN-Patrice Lumumba documents to retrace the university's history until the demise of the Soviet empire (1989-91), when 'Patrice Lumumba' disappeared as well, and 'UDN' was rechristened 'RUDN', the Russian Peoples' Friendship University. It does not provide a comprehensive history of the school and its students, but focuses on a number of central questions: what was the rationale behind its creation and how did its specificities compare to other Soviet schools frequented by Third World students? Who were the students who attended it, and how did the university function as an institution? The article also examines international reactions and argues that, partly in response, UDN underwent major improvements, but at the same time departed from its initial Third World concept. For all its accomplishments as a school, as a cultural policy venture UDN failed to convince 'developing' countries that a special institution was necessary for their nationals. ${ }^{17}$

From a longue durée perspective, Lumumba University is a tiny chapter in the history of the 'global exchanges' that Ludovic Tournès and Giles Scott-Smith have analysed so extensively. ${ }^{18}$ In the conjunction of decolonization and the global Cold War, however, following the paradigm set by Odd Arne Westad, UDN's history acquires significant dimensions: it becomes part of global Cold War history because it deepened Moscow's engagement with the non-European areas of the world, and constituted Soviet socialism's most ambitious attempt to 'go global' through higher education. ${ }^{19}$ Nonetheless, UDN was not alone in pursuing such objectives: most Eastern and Western Third World education policies operated more or less within the paradigm set by Westad until the logic of commercialization prevailed.

Nevertheless, unlike the majority of the largely established education policies and forms of international education, UDN was an exceptional venture. It stands, therefore, alongside the few

\footnotetext{
${ }^{12}$ William Nmle Appleton, Friendship University Moscow: the student trap, Stuttgart: Pro Libertate, 1965.

${ }^{13}$ The National Archives, Kew, UK (henceforth TNA), CO 1027/382, 'Measures for countering communist propaganda in Africa', 9 November 1962, p. 4.

${ }^{14}$ Tobias Rupprecht, 'Gestrandetes Flaggschiff: die Moskauer Universität der Völkerfreundschaft', Osteuropa, 60, 1, 2010, pp. 95-114.

${ }^{15}$ Cited by Jean-François Bayart, L'illusion identitaire, Paris: Fayard, 1996, p. 32.

${ }^{16}$ Luis Sepúlveda, L'Ouzbek muet et autres histoires clandestines, Paris: Métailié, 2015.

${ }^{17}$ The Soviets rejected the Western term 'Third World', which is used in this article for pragmatic reasons. Instead, they referred to the same group of countries using the term razvivaiushiesiia strany ('developing countries'), encouraging them to choose the non-capitalist path of development.

${ }^{18}$ See Ludovic Tournès and Giles Scott-Smith, 'A world of exchanges: conceptualizing the history of international scholarship programs (nineteenth to twenty-first centuries)', in Ludovic Tournès and Giles Scott-Smith, eds., Global exchanges: scholarships and transnational circulations in the modern world, New York: Berghahn Books, 2017, pp. 1-29.

${ }^{19}$ Odd Arne Westad, The global Cold War: Third World interventions and the making of our times, Cambridge: Cambridge University Press, 2005.
} 
unconventional initiatives, ideologically inspired institutions, and methods that showcased socialist modernity, provided solutions to urgent problems, constituted flagships of internationalist solidarity, and spearheaded the socialist world's cultural struggle for the Third World. They included not only the successful Cuban literacy campaign and the authoritative Soviet educational planning, but also institutions such as the workers' faculties that circulated from the USSR and East Germany to Vietnam and Mozambique; ${ }^{20}$ the boarding schools for Third World students on the Cuban Isla de la Juventud; ${ }^{21}$ and the vocational School of Friendship in Stassfurt, East Germany, which trained 900 Mozambicans. ${ }^{22}$ This article views UDN in this light, and seeks to understand its development beyond proclamations and contrasting accounts. The other Eastern bloc venture in higher education especially for Third World students was the University of the 17th of November, which was founded in Prague in 1961 in emulation of UDN. However, the Czechoslovaks closed the school in 1974 after disappointing results from a cost-benefit analysis, and as they reconsidered their Third World policy. ${ }^{23}$

In other words, not all ventures developed as expected: among other reasons, because Third World countries were active agents of international education and extremely concerned with the training of students. While Soviet officials were quick to realize this, two French socialist scholars, who had earlier entertained the idea of creating a kind of a 'French Lumumba University', had been confronted with strong African reactions. It is worth focusing for a while on this illuminating confrontation that took place during the Conference of Dakar-Abidjan on the eve of decolonization, only two months before Khrushchev's announcement in Jogjakarta.

\section{A French international university for the underdeveloped countries}

The conference on the 'Scientific and Technical Research and the Economic and Social Development of African Countries' held in Dakar and Abidjan from 14 to 21 December 1959 was a major event. So too was the address by the French President, Charles de Gaulle, to the Federal Assembly of Dakar, on the eve of the conference, when he accepted that the Mali Federation - the ephemeral union between Senegal and Mali - could acquire 'international sovereignty'. This was the death knell of the old empire. ${ }^{24}$

Under those circumstances, the Vice-President of the Mali Federation, Mamadou Dia, addressed 200 conference participants at the newly founded Dakar University with a short speech entitled 'The mystique of development', and urged them to find the answers to the aspirations of African countries. ${ }^{25}$ Education was a burning issue. 'The essential problem with regard to the future', Félix Houphouët-Boigny, Prime Minister of Ivory Coast, stressed, 'is first and foremost the development of education. ${ }^{26}$ During a heated debate, in a session chaired by the prominent Senegalese-French lawmaker Gabriel d'Arboussier, the director of the Paris Institute for the Study of Economic and Social Development, Henri Laugier, and the economist Georges Fischer put forward a radical agenda. Traditional French education was 'harmful' for Africa, they argued. Instead, Africa needed 'centres for accelerated training' and 'the introduction of shock

\footnotetext{
${ }^{20}$ Ingrid Miethe et al., Globalisation of an educational idea: workers' faculties in Eastern Germany, Vietnam, Cuba and Mozambique, Munich: De Gruyter Oldenbourg, 2019.

${ }^{21}$ Christine Hatzky, Cubans in Angola: South-South cooperation and transfer of knowledge, 1976-1991, Madison, WI: University of Wisconsin Press, 2015, pp. 206-12.

${ }^{22}$ Tanja Müller, Legacies of socialist solidarity: East Germany in Mozambique, Lanham, MD: Lexington Books, 2014.

${ }^{23}$ Marta Edith Holečková, "Konfliktní lekce z internacionalismu: studenti z "třetiho světa" a jejich konfrontace s českým prostředim, 1961-1974 (Conflicting lessons of internationalism: students from the "Third World" and their encounter with Czechoslovak society, 1961-1974)', Soudobé Dějiny (Contemporary History), 20, 1-2, 2013, pp. 158-76.

${ }^{24}$ Frederick Cooper, Citizenship between empire and nation: remaking France and French-Africa, 1945-1960, Princeton, NJ: Princeton University Press, 2014, pp. 368-71.

${ }^{25 ،}$ 'Conférence de Dakar-Abidjan', Cahiers de la République, special issue, January 1961, p. 35.

${ }^{26}$ Ibid., p. 55 , emphasis in original.
} 
pedagogies'. Invoking the Soviet Union's peculiar method for increasing productivity, they concluded that the goal would be to reach a higher, "Stakhanovite" pace of [educational] activity". ${ }^{27}$

Elaborated at a rapid and truly Stakhanovite pace, these ideas were made public in early March 1960 in the opening article of the first issue of the journal Tiers-Monde, under the title 'For an international university at the service of underdeveloped countries' ${ }^{28}$ Fischer and Laugier maintained that Africa needed its own intellectual, scientific and technical experts, able to assume responsibility for their countries' destinies as quickly as possible'. Convinced that their university was the right solution, they were nonetheless confronted with the reactions of African elites. 'Most of them', Laugier and Fischer noted regretfully and with considerable disappointment, 'reject with more or less indignation, and always firmly, every special training institution, which may be suited to their situation; all such kind of training is dismissed as low-quality education, tailor-made training, and is considered as an intolerable reminiscence of the old relations between colonizers and colonized. ${ }^{29}$

Africans, as d'Arboussier also confirmed, 'blasted away' at all special education institutions. ${ }^{30}$ French personalities and proponents of the established system objected as well, and the idea of an international university for underdeveloped countries was abandoned. It appears from the final footnote of their text that Laugier and Fischer, at least, found consolation in UDN, where their agenda of modernization through suitable education appeared to be vindicated.

\section{Lumumba University: premises, aims, and policies}

Against the background of decolonization and the emergence of the Third World, the foundation of UDN was predicated on a number of optimistic assumptions. Seeing the 'awakening of the East' as the fulfilment of Lenin's predictions, the Soviet leadership considered that a Soviet-Third World alliance was imminent. Fostering political and economic ties with non-communist countries, which in most cases advocated anti-imperialism or socialism, was intended to encircle the capitalist world and accelerate the march of communism towards victory. A further assumption was that the USSR, with its experience in 'modernizing' the backward Tsarist empire, could serve as a model and transfer its knowledge to less developed countries. The latter, it was further assumed, would acknowledge Moscow's authority and respond to solidarity with gratitude.

On the basis of these assumptions, the CPSU embarked on a new Third World cultural policy, in which UDN constituted the flagship. On the symbolic level, by naming UDN after the nationalist leader Patrice Lumumba, Moscow trumpeted the message that it was embracing anti-imperialist struggles led by non-communist actors. Similar political symbolism had been central in the short-lived University of the Toilers of China (1925-30), created by the Communist International in Moscow and named after the Chinese 'bourgeois nationalist' leader Sun Yat-Sen. At that time Sun Yat-Sen University, which primarily admitted members of the nationalist Guomindang Party, had represented an attempt to materialize the tactical alliance between Chinese nationalists and communists. ${ }^{31}$ However, Lumumba University sharply differed from Sun Yat-Sen and from the Communist University of the Toilers of the East (1921-37), which were both political schools for cadres and revolutionaries, in that it was an academic institution. As such it had the primary

\footnotetext{
${ }^{27}$ Ibid., pp. 360, 376. Named after Aleksei Stakhanov, the miner-hero who apparently hewed fourteen times as much coal as the average, Stakhanovism became an officially sponsored movement meant to push workers and their managers to raise productivity. See Lewis Siegelbaum, Stakhanovism and the politics of productivity in the USSR, 1935-1941, Cambridge: Cambridge University Press, 1988.

${ }^{28}$ Georges Fischer and Henri Laugier, 'Pour une université internationale au service des pays sous-développés', TiersMonde, 1, 1-2, 1960, pp. 17-26.

${ }^{29}$ Ibid., p. 18.

${ }^{30}$ 'Conférence de Dakar-Abidjan', p. 362.

${ }^{31}$ The collapse of this alliance in 1927 meant that the university was closed down in 1930.
} 
mission to train physicians, engineers, economists, and administrators, who, as HouphouëtBoigny argued in Abidjan, would 'ensure management in all state mechanisms'. ${ }^{32}$

UDN was not exactly ground-breaking in the provision of Soviet educational aid to, nor cooperation with, the South. Between 1956 and 1960, nearly 1,800 Third World students, not necessarily communists, had already been enrolled in Soviet universities. A few, such as the Indonesians, came with scholarships provided by their government. Iraqis and Egyptians were sponsored jointly by their home government and the Soviet government. Others were fully sponsored by the USSR, but selected by the sender country or UNESCO. The last group, and the ones most likely to be radicals, were those sponsored by Soviet social and theoretically non-state organizations. Unlike regular Soviet schools, however, UDN was unique thanks to a number of characteristics, which accounted for its symbolic, educational, and political raison d'être.

To begin with, it was a university especially created for students from the Third World. Students from the so-called 'First World', other than a handful of Japanese communists, or from the socialist countries (the 'Second World'), other than Soviets, were not eligible. In1960/61 the school boasted 59 Soviets alongside 538 foreigners, approximately 10\%. This proportion grew to $16.7 \%$ in $1964 / 65$ and $23.9 \%$ in 1969/70. ${ }^{33}$ Second, unlike other Soviet schools, UDN did not admit students sponsored by the sender countries. Full-funding of all students, including medical care, housing, allowances for warm clothes and holidays, and a round-trip ticket were available until 1989. Along with the ratio of four students per faculty member throughout the 1960 s, these expenses made the UDN a costly undertaking. In 1965, its annual cost reached 9,052,190 roubles, of which $43 \%$ covered the students' needs. ${ }^{34}$ From 1960 to 1990 , without including the construction and equipment of the new campus, where UDN moved in the mid 1970s, the cost of training foreign students amounted to 250 billion roubles. ${ }^{35}$

A further particularity was that, although the curricula were subject to the supervision of the Ministry of Higher and Specialized Secondary Education (henceforth Minvuz), UDN was formally administered by a council, which included four social organizations and its founding members: the Soviet Afro-Asian Solidarity Committee, the Union of Soviet Societies for Friendship and Cultural Relations with Foreign Countries, the All-Union Central Council of Trade Unions, and the Committee of Youth Organizations. In this way it could appear to act without the knowledge of the Soviet government, yet in reality serve its objective to reach out to communists or sympathizers, who otherwise would never have been allowed to study in the USSR. Thus, even though UDN was admitting and paying the scholarships of students selected by foreign governments, it was mostly a school for members of communist and anti-imperialist organizations.

As regards the first group, during the 1960s, students came either from non-aligned Asian countries, especially India, Indonesia, Laos, and Sri Lanka, or from countries allied to Moscow, such as Cuba or Mali, whose governments in both cases were very eager to train students at UDN. Students in the second group were generally members of Latin American, Asian, and Middle Eastern communist parties; of African nationalist and left-leaning movements, such as the Union des Populations du Cameroun, the Partido Africano da Independência de Guiné e Cabo Verde, or the Algerian Front de Libération Nationale (FLN); of youth organizations and trade unions; or of pro-Soviet cultural societies; or were candidates recruited on the recommendation of the students' unions of UDN. ${ }^{36}$ Many of them travelled to the USSR with a passport issued by a neighbouring country that supported their cause. Some students were also admitted

\footnotetext{
${ }^{32 ‘ C o n f e ́ r e n c e ~ d e ~ D a k a r-A b i d j a n ’, ~ p . ~} 55$.

${ }^{33}$ Central Municipal Archive of Moscow (Tsentral'nyi Munitsipal'nyi Arkhiv Moskvy; henceforth TsMAM), fond 3061, op. 1, d. 42 , p. 112 ; d. 420 , pp. 1-10; and d. 1103 , p. 55.

${ }^{34}$ RGASPI, fond. 3, op. 5, d. 132.

${ }^{35}$ Or US $\$ 342.5$ billion with the exchange rate of 1975 . I take 2,600 roubles as an average cost of a student per year.

${ }^{36}$ State Archive of the Russian Federation (Gosudarstvennyi Arkhiv Rossiiskoi Federazii; henceforth GARF), fond 9606, op. 2, d. 77, pp. 179-84.
} 
on the recommendation of Soviet embassies, cultural centres, or journalists working abroad. ${ }^{37}$ In terms of regions, with the exception of Cubans in the 1960s, who otherwise were quickly promoted from the 'Third' to the 'Second World' and were no longer eligible for acceptance to UDN, and of Nicaraguans, who in the 1980s were also selected by the Sandinista government, almost all Latin Americans were recruited on the recommendation of parties and organizations. The same was true of students from Arab countries, with the exception of those from South Yemen, the only country whose rulers espoused Marxism-Leninism and seized the opportunity to train the national elites at UDN.

These political criteria should ideally have corresponded to the social ones that Khrushchev had stressed in Jogjakarta, namely, to recruit youths 'from poor families'. Being himself a former worker of peasant origin and promoted into the elites under Stalin's affirmative action, Khrushchev was personally invested in the 're-proletarianization' of universities, which informed his controversial 1958 educational reform. ${ }^{38}$ Both the social organizations and the UDN rector, Sergei Rumiantsev, were instructed by the CPSU to give priority to candidates with working or lower-class background, who were expected to be grateful and reliable comrades.

Objectively, however, this task was complicated because of the lack of a working class in nonindustrialized countries, and of the small pool of qualified candidates coming from poor families. 'Youths from poor families do not have the possibility to receive the necessary education to qualify for university studies', the Indian ambassador in Moscow once said in reaction to these requirements. ${ }^{39}$ Nevertheless, based on statements of the enrolees, UDN professors N. Egorov and N. Sofinskii calculated that, from 1960 to 1968, 54.6\% of students had been of either working-class or peasant background, a proportion that reached $57.8 \%$ in $1971 / 72 .{ }^{40}$ Yet in the same academic year, among 3,039 Third World students studying all over Soviet Ukraine, this percentage was much lower, reaching only $34.9 \%{ }^{41}$ However, by the end of the 1970 s, students with workingclass or peasant background made up approximately $67 \%$ at UDN and $46.2 \%$ in Ukraine. ${ }^{42}$

Such figures allowed UDN to claim that it had fulfilled its mission to practise both nation-based and class-based affirmative action at the international level. For all the bias of Soviet sociological surveys and claims, it was nonetheless true that UDN welcomed Iraqi and Syrian communists persecuted by the ruling Baath parties, members of minorities such as Kurds or Lebanese Druze, Palestinian and Tutsi refugees, Latin Americans with working-class backgrounds, and Nigérien petit peuple. ${ }^{43}$ It was more difficult to recruit female students, whose proportion in $1969 / 70$ reached $15.4 \%$, against $11.3 \%$ throughout the USSR, and $18.2 \%$ worldwide in $1968 .{ }^{44}$ This $15.4 \%$ was predominantly made up of Latin Americans (23.4\%) and Greek Cypriots (37.9\%), rather than groups from Asian (13.6\%), Sub-Saharan African (10\%), and Arab countries

\footnotetext{
${ }^{37}$ Klaas van Walraven, The yearning for relief: a history of the Sawaba movement in Niger, Leiden: Brill, 2013, pp. 418-20.

${ }^{38}$ Laurent Coumel, 'The scientist, the pedagogue and the party official: interest groups, public opinion and decision-making in the 1958 education reform', in Melanie Ilic and Jeremy Smith, eds., Soviet state and society under Nikita Khrushchev, London: Routledge, 2009, pp. 66-85.

${ }^{39}$ TsMAM, fond 3061, op. 1, d. 1413, p. 54, Discussion between Ambassador K. Shelvankar and Rector Vladimir Stanis, 29 December 1971.

${ }^{40}$ RGASPI, fond 1, op. 39, d. 143, p. 10, Report of 4 June 1968 (henceforth 'Egorov and Sofinskii's report'). For 1971/72, see another report: TsMAM, fond 3061, op. 1, d. 1548, pp. 272-6.

${ }^{41}$ Central State Archives of Public Organizations of Ukraine (Tsentral'nyi Derzhavnyi Arkhiv Gromads'kikh Ob'ednan' Ukraini; henceforth TsDAGO), fond 7, op. 20, d. 1030, p. 20, Report of the Communist Youth League (Komsomol) of Ukraine, February 1972.

${ }^{42}$ For UDN, the figure corresponds to the academic year 1978/79: see RGASPI, fond 3, op. 3, d. 588a, p. 6. The second figure is based on a sample of 2,279 students studying in Ukraine in 1980/81: see Central State Archives of Supreme Bodies of Power and Government of Ukraine (Tsentral'nyi Derzhavnyi Arkhiv Vishchikh Organiv Vladi ta Upravliniya Ukraini; henceforth TsDAVO), fond 4621, op. 13, d. 6281-8.

${ }^{43}$ The little folk, according to Walraven, Yearning for relief, p. 46.

${ }^{44}$ For the USSR, see GARF, fond 9606, op. 1, d. 3532. For world data, see UNESCO, Statistics of students abroad 1962-68, Paris: UNESCO, 1971, p. 32.
} 
(6.3\%). ${ }^{45}$ Unlike mainstream schools, which boasted large numbers of Soviet female students, UDN was an overwhelmingly male university, something that the male students found frustrating.

Recruiting the majority of students primarily according to political and social criteria presented challenges. One such challenge was to teach the heterogeneous student body of the first cohort, since $26 \%$ of enrolees had not completed secondary education. ${ }^{46}$ For these enrolees, the solution was the preparatory faculty, an institution inspired by the workers' faculties (rabochie fakul'tety) that the Bolsheviks had set up in 1918 to prepare students with working-class or peasant background for higher education. ${ }^{47}$ Following the mass arrival of Third World students in the late 1950s, several universities created one-year preparatory faculties, whose principal mission was to teach Russian to foreign students. The preparatory faculty of UDN, however, could last up to three years and provided all the basic secondary-level courses to allow ill-prepared students to receive a certificate, giving them access to higher education on successful completion of their exams. In 1963/64, however, 835 of the 2,089 UDN students (40\%) were still studying at the preparatory faculty. In 1969/70 this percentage had fallen to $25.8 .{ }^{48}$

The six regular faculties were, in order of students enrolled, engineering (29\%), medicine (20.3\%), economics and law (17.1\%), agriculture (12.1\%), history and philology (12\%), and natural sciences and mathematics $(9.5 \%) .{ }^{49}$ Graduates were awarded a diploma, which the Minvuz recognized as a Master's degree. This diploma gave access to a $\mathrm{PhD}$ (aspirantura) programme, as did diplomas awarded by all Soviet universities. But studies at UDN were one year shorter than at other universities, lasting five years at the Faculty of Medicine and four at the rest. To compensate for the shortened programmes, there were thirty-six hours of classes per week (the average Soviet school had thirty hours). Thus, even though until October 1968 Third World students at UDN and all over the USSR were exempted from the courses on Marxism-Leninism, studies at UDN were particularly exhausting.

The relevance of the courses to the students was a thorny issue. In a few cases relevance did shape content. Lecturers in engineering, for instance, placed emphasis on the geological features of the Southern hemisphere and the construction of materials used in this region. Courses on tropical medicine or the economics of 'developing' countries were also taught, even though most lecturers had never been to Third World countries. Otherwise, during the 1960s, both the specializations and the curricula were identical to those of ordinary Soviet faculties, which trained a narrowly specialized workforce for the diversified Soviet economy. ${ }^{50}$ In terms of specializations and courses, therefore, UDN could hardly justify the Third World recruitment.

On top of that, optional seminars and conferences, political and cultural events, excursions, and holidays were meant to cultivate the students' sympathy for the USSR and communism. Discipline was required, and during the first years passports were impounded to prevent students from travelling abroad, a measure that prompted Appleton to call UDN a 'student trap'. Yet difficulties of adaptation and disillusionment with the political atmosphere, as well as living conditions, occasionally sparked unrest. When in December 1963 a Ghanaian student was found dead in Moscow under mysterious circumstances, nearly four hundred African students caught the supposedly impeccable Soviet surveillance system by surprise and marched on Red Square to denounce racism, dealing a blow to the USSR official image of racial tolerance. Many of them came from UDN, where unrest continued. Thirteen students finally left the USSR for West Germany. ${ }^{51}$

\footnotetext{
${ }^{45}$ TsMAM, fond 3061, op. 1, d. 1103, p. 55.

${ }^{46}$ GARF, fond 5451, op. 45, d. 1543, pp. 93-7.

${ }^{47}$ Sheila Fitzpatrick, Education and social mobility in the Soviet Union 1921-1943, Cambridge: Cambridge University Press, 1979, p. 4-5.

${ }^{48}$ TsMAM, fond 3061 , op. 1, d. 163 , p. 33; d. 1103, p. 5.

${ }^{49}$ Average of the years 1964/65, 1969/70, 1976/77, 1981/82, 1987/88.

${ }^{50}$ Seymour Rosen, The development of Peoples' Friendship University in Moscow, Washington, DC: U.S. Government Printing Office, 1972, pp. 6-7.

${ }^{51}$ Julie Hessler, 'Death of an African student in Moscow: race, politics, and the Cold War', Cahiers du Monde Russe, 47, 1-2, 2006, pp. 33-64.
} 
Disillusionment and academic failure, the unforeseen consequences of recruiting students according to political criteria, constituted the major causes of student absences, withdrawal, or expulsion. Of approximately 4,800 students enrolled between September 1960 and May 1968, 226 dropped out of their own volition, 225 were expelled for 'immoral behaviour, major violation of discipline, academic failure or non-attendance of classes', 122 went on holidays abroad and never returned, 49 abandoned their studies citing family reasons, and, finally, 68 dropped out 'because they could not afford the climate and fell sick'. ${ }^{52}$ According to this data, the overall dropout rate reached $14.4 \%$. In reality, it was much higher, because among the latest enrolees there were many students who had not yet dropped out (but would do so in the future), and also because numerous students who transferred to technical schools were not included. ${ }^{53}$

Still, by Soviet standards the rate was high. Of 3,560 Third World students enrolled at preparatory faculties in Ukraine between 1975 and 1981, only 126 (3.5\%) dropped out and left the USSR. ${ }^{54}$ In mainstream faculties all over the USSR, the dropout rate was even lower, even in the 1960s, meaning that almost all Third World students enrolled graduated. ${ }^{55}$ At UDN, however, the relatively high dropout rate added to the rate of students lagging at the preparatory faculty, and thus signified fewer graduates over time. Of nearly 4,200 students enrolled from 1960/61 to 1966/ $67,2,808(66.8 \%)$ graduated in the period $1965-71 .{ }^{56}$ For a school that in 1962/63 hosted $29.9 \%$ and in 1969/70 25.5\% of all Third World students in the USSR and constituted the biggest Soviet investment in training a friendly intelligentsia, the failure to produce graduates according to the plan was a matter of concern. It was not the only one, for adverse reaction was also increasing.

\section{Reactions against Lumumba University}

Reactions against Soviet practices of recruitment and indoctrination, and student denunciation of racial discrimination and criticism of their poor living conditions in the USSR, began before UDN had even opened its doors. In particular, accounts of disillusioned Africans, former students at Moscow State University (MGU), appeared in several languages and were used in Western propaganda to caution Africans that Moscow should not be regarded as their Mecca. ${ }^{57}$ Against the background of anti-communism, the founding of UDN and its admission and training policies lent ever more credence to these accounts and increased international suspicion. The Cabinet Office of Prime Minister Harold Macmillan was doing its part by warning all members of British Commonwealth against Soviet intentions, and stressing that 'the pro-Rector of the Lumumba Friendship University in Moscow' was 'a KGB general'. ${ }^{58}$

In most of these Cold War battles, Africans were prominent. In June 1961, a Nigerian expelled from UDN published a fictional testimony in the British Sunday Telegraph alleging that the Soviets trained students in guerrilla tactics to help stage communist revolutions. ${ }^{59}$ Published in West Germany in 1965, Friendship University Moscow: the student trap, by Appleton, was far more honest, but still written with the explicit purpose of confirming the UDN's invidious

\footnotetext{
${ }^{52}$ Egorov and Sofinskii's report, p. 10.

${ }^{53}$ Alvin Rubinstein, 'Lumumba University: an assessment', Problems of Communism, 20, 6, 1971, p. 64.

${ }^{54}$ TsDAVO, fond 4621, op. 13; fond 4621, op. 1, d. 3875, 6285, 6286, 6288.

${ }^{55}$ The graduation rate was high because students had scholarships, they were not allowed to work, and they attended remedial courses. For some indications of lower standards, see Constantin Katsakioris, 'Creating a socialist intelligentsia: Soviet educational aid and its impact on Africa', Cahiers d'études africaines, 226, 2, 2017, p. 271.

${ }^{56}$ TsMAM, fond 3061, op. 1, d. 1381, p. 7, Report of the Rector, 17 June 1971.

${ }^{57}$ I refer to Jan Carew's novel Moscow is not my Mecca, London: Secker, 1964. Carew later switched sides and congratulated the 'Soviet Bloc countries' for crushing the Czechoslovak uprising, arguing that 'the Soviet Union acted with commendable restrain and humanity throughout the Czechoslovak crisis'. Russian State Archive of Literature and Arts, fond 631, op. 27, d. 503, p. 1, Jan Carew to the Soviet Union of Writers, 27 October 1968.

${ }^{58}$ TNA, Cabinet Office, 11/4609, p. 13.

${ }^{59}$ Sergei Mazov, 'Afrikanskie studenty v Moskve v god Afriki po arkhivnym materialam (African students in Moscow in the year of Africa through archival documents)', Vostok (East), 3, 1999, pp. 90-3.
} 
intentions. Propaganda battles were also fought on African soil, as happened after the expulsion from the USSR of seven Somali students in April 1961. 'The Westerners', wrote the Soviet ambassador in Mogadishu, Georgi Fomin, on May 22, 'continue to use the seven Somali students dismissed from MGU to spread anti-Soviet propaganda both inside the Republic of Somalia and abroad. In particular, a leaflet written in Italian language, entitled "The communists speak ... Africans reply: ten truths about the Peoples' Friendship University in Moscow” is widely distributed in Mogadishu. ${ }^{60}$

A vitriolic reaction against UDN came from the predominantly white and ideologically liberal National Union of South African Students (NUSAS), an organization that opposed apartheid and sought a multi-racial alliance. Drawing on various African accounts, the NUSAS president, John Shingler, addressed a letter to the president of the Soviet Friendship Association with the Peoples of Africa and well-known Africanist, Ivan Potekhin, in October 1960, denouncing the Soviet government and UDN:

So bad has the situation now become that the government of the USSR has felt it necessary to segregate the non-whites from the whites, placing them to a separate University institution altogether. To disguise this discriminatory practice the government has hypocritically indicated that the University has been created as a special gesture to the non-white peoples of the world and has gone so far as to call it 'The University of Friendship of Peoples'. We want to know why it would be necessary to put students into separate institutions, thus depriving them of contact with the people of the country which they are visiting, where they are only to meet their own kind in order to further this so-called friendship. We believe that this University will serve only as an indoctrination center for the ideology which your government holds ... ${ }^{61}$

This letter reached Moscow through the Netherlands and prompted an angry reply by Potekhin in April 1961. After accusing Shingler of re-iterating 'anti-Soviet propaganda', he retorted that UDN had been created 'not to segregate the students from the countries of Asia or Africa from the Soviet students, but because Moscow State University, in spite of the fact that more than 25 thousand students including Africans' were studying there, was 'too small for a great number of foreign students wishing to receive education in the USSR, the country of highly developed culture, science and technology ${ }^{62}$ Notwithstanding Potekhin's political rhetoric, by the end of 1961 there were 10,765 Asian, African, and Latin American students, 6,261 of whom came from socialist countries and the remaining 4,504 (41.8\%) from Third World countries, studying not only at MGU or UDN but all over the USSR. ${ }^{63}$ Shingler's argument that UDN had been created to 'segregate the non-whites from the whites' was projecting the apartheid policies of South Africa onto the USSR.

For all its bias, however, the letter echoed the views of Africans, who castigated the school for segregation. Such views were not uncommon. When the American political scientist Alvin Rubinstein visited the USSR in 1971, he found that African students studying at mainstream and more prestigious schools referred to Lumumba University as a 'colonial establishment'. ${ }^{64}$ African officials held similar views. In March 1969 the Soviet ambassador in Zambia, Sergei Slipshenko, visited the Ministry of Education to obtain the two lists of students to be sent to the USSR, the ones to study at regular schools and the others at UDN, but the second list was not ready. Although Zambians replied to his enquires that they had been busy, Slipshenko

\footnotetext{
${ }^{60}$ GARF, fond 9576, op. 14, d. 18, p. 78, Fomin to the Soviet Ministry of Foreign Affairs, 22 May 1961.

${ }^{61}$ GARF, fond 9576, op. 14, d. 21, p. 245, Shingler to Potekhin, 31 October 1960.

${ }^{62}$ GARF, fond 9576, op. 14, d. 21, p. 250, Potekhin to Shingler, 25 April 1961.

${ }^{63}$ The socialist countries included North Vietnam, China, North Korea, Mongolia, and Cuba. GARF, fond 9606, op. 1, d. 869 , pp. $44-49$.

${ }^{64}$ Rubinstein, 'Lumumba University', p. 68.
} 
was under no illusions: 'In Zambian circles', he informed Moscow, 'the opinion is widespread until today that UDN is an educational institution especially created for Africans and in which they are "segregated".' 65

On a similar note, Arab governments questioned Moscow's decision to create a university especially for Third World students. 'The government of Morocco', stated a diplomatic note addressed to the Soviet Ministry of Foreign Affairs in October 1960, 'does not intend to send students to the "Peoples' Friendship" University', adding that:

The interest in sending students to the USSR would be to allow them to connect with the Soviet cultural and student milieu, and not to get mixed with Afro-Asian or Latin American students, who make up the "Peoples' Friendship" University, and whom they can meet in their own countries. Besides, the government of Morocco recognizes and accredits diplomas only of state and not of private or semi-governmental institutions. ${ }^{66}$

Soviet diplomatic missions were, however, quick to realize that in some Arab countries the rejection of UDN was less due to the relative isolation of Arab students from the Soviet milieu, and more related to the very Third World 'mixture' of UDN's student body, and sometimes to coexistence with students from Sub-Saharan Africa, for whom Patrice Lumumba University was perceived to be reserved. As an Iraqi UDN graduate complained to a Soviet diplomat, his degree was not recognized because the Ministry of Education of Iraq 'considered Friendship University as a party school, in which only ill-educated Negros study'. ${ }^{67}$ Similarly, a Tunisian diplomat informed the Soviet embassy that 'the Tunisian Commission for the allocation of scholarships decided against the enrolment of Tunisian students at Lumumba University, considering that studies at this university constitute a form of discrimination against Tunisians, because young Tunisians have an education level comparable to that of European students, while the university is suited to African students whose level is lower' ${ }^{68}$

Racial and cultural hierarchies therefore lay behind some reactions, while the name 'Patrice Lumumba' reinforced the false impression that UDN was reserved for sub-Saharan Africans. Beyond these prejudices, however, the major reason of anxiety was UDN's recruitment policy, which Western-oriented countries strongly opposed. Morocco affirmed that granting scholarships without the approval of Moroccan authorities was 'unacceptable'. ${ }^{69}$ The Nigerian government issued recurrent notes protesting against the recruitment of students through political channels. Enrolled through such channels, Biafran Nigerians at UDN created a separate union and militated for Biafra's independence during the Nigerian Civil War (1966-70). Violent clashes erupted in UDN dormitories. As the Kremlin sided with the Nigerian Federal Government, the Soviet authorities put pressure on Biafran students to disavow separatism and reach a reconciliation with the Nigerian embassy. Meanwhile, in Lagos, the authorities stopped the departure of students other than holders of state scholarships. ${ }^{70}$

At the same time, even socialist countries viewed UDN recruitment policies with suspicion. Kwame Nkrumah's Ghana and Modibo Keita's Mali, for instance, were eager to assist students from neighbouring countries, particularly members of opposition movements from Nigeria, Cameroun, Niger, or Senegal, to travel to the USSR. When it came to their own nationals, however, both governments issued diplomatic notes criticizing the Soviet recruitment policies and asking

\footnotetext{
${ }^{65}$ GARF, fond 9606, op. 1, d. 3962, p. 43, report from Lusaka, 14 March 1969.

${ }^{66}$ Foreign Policy Archives of the Russian Federation (Arkhiv Vneshnei Politiki Rossiiskoi Federatsii; henceforth AVPRF), fond 'Posol'stvo v Marokko', op. 3, d. 3, p. 50, report from Rabat, 20 October 1960.

${ }^{67}$ GARF, fond 9606, op. 1, d. 2703, p. 36, Report of the Soviet embassy, 17 August 1966.

${ }^{68}$ GARF, fond 9518, op. 1, d. 531, p. 80, Report from Tunis, 19 August 1963.

${ }^{69}$ AVPRF, fond 'Posol'stvo v Marokko', op. 3, d. 3, p. 48, report from Rabat 12 October 1960.

${ }^{70}$ RGASPI, fond 3, op. 8, d. 1152, p. 101.
} 
that UDN admit only students selected by their commissions. ${ }^{71}$ Similarly, the Algerian FLN, which eagerly sent students to UDN when it was a national liberation movement, changed course after 1962, when it became the party ruling independent Algeria. In April 1963, President Ahmed Ben Bella asked the Soviets to close non-governmental channels for granting scholarships to Algerians to study at UDN. ${ }^{72}$ 'We are eager to train our specialists in the USSR only when cooperation is under government control', an Algerian official informed the Soviet embassy in March $1964 .^{73}$ The standoff intensified after Ben Bella was ousted by Houari Boumedienne in June 1965. Algerian students at UDN denounced Boumedienne's coup. In response, on 19 December 1965, the day that Boumedienne arrived on an official visit to the USSR, the Algerian embassy handed the Soviets a list with the names of four UDN students and requested their repatriation. ${ }^{74}$ When the demand was not met, Algerian authorities did not hesitate to place UDN on their black list.

Reactions of foreign governments were not limited to verbal notes. Measures were taken to prevent students from departing to study at UDN and to punish those who circumvented state commissions. As early as 1961, Egyptian authorities prevented three holders of UDN scholarships from leaving the country. ${ }^{75}$ Similarly, four holders of UDN scholarships from Benin experienced disillusionment when, according to the Soviet ambassador, 'on August 21 [1966], just as they were ready to fly to Moscow to study at the Peoples' Friendship University ... five minutes before the take-off, a police officer ordered them to get out of the plane'. ${ }^{76}$ Two years later, only four out of thirty-nine holders of UDN scholarships from Pakistan were allowed to travel to the USSR.

For returning students the consequences could be tougher. 'Among all graduates of Soviet higher and technical education institutions, only those of Lumumba University are conscripted into the army', noted the Soviet embassy in Jakarta two months after the socialist President Sukarno was toppled..$^{77}$ Singled out as a 'Moscow spy', a Camerounian female student was jailed, whereas many among her peers migrated to western European or neighbouring African countries. ${ }^{78}$ Graduates were forced to migrate or opted to do so. In some cases, migration was a decision taken in view of the obstacles they faced to having their degree recognized.

\section{The UDN degree}

Unless there was a coup against a socialist regime, the group of graduates who had been selected by state commissions did not face difficulties in having their degree recognized. However, these conditions did not always apply to the group of students sent to the USSR by opposition parties. In particular, UDN graduates, who made up a sizeable part of this second group, could face even greater difficulties. In several contexts, therefore, UDN graduates constituted a sort of third group or 'third-class' graduates. The member of a communist party who had studied at Kiev or Leningrad State University was usually much more fortunate than a comrade who had attended Lumumba. Such hierarchies were even more clear-cut in Arab countries.

In Iraq, the pro-Soviet government of Kassem decided in December 1962, to 'recognize the diplomas of all Soviet education institutions with the exception of the Peoples' Friendship University Patrice Lumumba'. ${ }^{79}$ Yet, when Kassem was ousted by the Baath Party in February, 1963 , the majority of the 1,266 Iraqis studying in the USSR, who refused to pledge allegiance to Baath, were targeted by the regime. Students at UDN remained a target for longer. Even as

\footnotetext{
${ }^{71}$ GARF, fond 9576 , op. 14 , d. 58 , pp. 6-18.

${ }^{72}$ GARF, fond 9518 , op. 1 , d. 540 , p. 320.

${ }^{73}$ GARF, fond 9518, op. 1, d. 489, p. 164.

${ }^{74}$ GARF, fond 9606, op. 2, d. 172, p. 27.

${ }^{75}$ GARF, fond 9606, op. 1, d. 940, p. 134, Egyptian Deputy Minister of Education, 12 April 1961.

${ }^{76}$ GARF, fond 9606, op. 1, d. 2703, p. 21.

${ }^{77}$ GARF, fond 9606, op. 2, d. 172, p. 23, Report of 30 November 1965.

${ }^{78}$ GARF, fond 9606, op. 2, d. 267, p. 48, Report of the Soviet ambassador in Cameroun, 9 March 1967.

${ }^{79}$ GARF, fond 9606, op. 2, d. 96, p. 70, Statement of an Iraqi official reported by the Soviet embassy in Baghdad.
} 
Soviet-Iraqi relations improved, a professor from Baghdad University, who was dispatched to the USSR in July 1968 to inquire about the studies of Iraqis, concluded that, 'in comparison with the other Soviet institutions of higher education, the academic level at UDN-Patrice Lumumba' was 'much lower'. ${ }^{80}$ One year later, fourteen Iraqi graduates of UDN addressed a letter to the rector, Sergei Rumiantsev, urging him and the Soviet government to press the Iraqi side to recognize the UDN degree. ${ }^{81}$

Syria, the biggest Third World exporter of students to the USSR after 1967, signed an agreement with Moscow in 1968, which provided for the recognition of Soviet degrees. However, this agreement did not apply to UDN. The reason, according to an official at the Syrian Ministry of Education, himself a graduate of MGU, was that UDN was recruiting students without the knowledge of the Syrian government. ${ }^{82}$ UDN graduates faced stark consequences. 'Our government does not recognize the degrees of the Peoples' Friendship University even though this is an obligation according to the agreement signed between Syria and the USSR last year', a group of graduates of the Faculty of Medicine wrote to Rumiantsev on 18 March 1969, adding: 'Being in a very difficult situation ... deprived of the possibility to work on our specializations, we ask you to raise the question of the recognition of the UDN degrees through the Soviet Ministry of Education to our government. ${ }^{\text {'83 }}$

While Morocco, Algeria, and Egypt ruled out recognition of the UDN degree, Lebanon in 1967 and Iraq in 1969 imposed terms. One of these stipulated that only graduates who had completed secondary school before attending university could have their degree recognized. Soviet officials complied with this regulation, perhaps with relief. When a delegation of the Lebanese Communist Party visited the Minvuz and requested a scholarship for a member who had not completed secondary education, a Soviet official showed them the Lebanese government's note and asked them 'to choose only candidates with the required educational level'. ${ }^{84}$

As well as betraying political anxieties, these measures, which focused on the shortened programmes and on students without the required qualifications, reflected dismissive views about the quality of training. Such views were common in Tunisia, where the authorities 'evoked the easier study programmes' to justify the non-recognition of the UDN degree. ${ }^{85}$ 'My degree is not recognized and I am obliged to work as a trainee doctor', a Tunisian graduate of the Faculty of Medicine wrote to Rumiantsev in November 1968, adding: 'With the exception of those who attended UDN-Lumumba University, all Tunisian citizens who received education in the USSR work as established specialists, their diplomas have been accredited. 86

UDN graduates faced obstacles in other countries too. In Sri Lanka, the right-leaning United National Party, which came to power in 1965, refused to recognize the degrees of UDN graduates, and the anti-communist Indonesian regime did the same after $1966 .{ }^{87}$ That year, the ousting of President Nkrumah heralded troubles for the hundreds of returning Ghanaians. The 'Russian doctors', as Soviet-educated physicians were dismissively called, became the target of a public campaign. Published in the Legon Observer of the University of Ghana in October 1967, an article by a Ghanaian doctor lamented the low admission requirements and shortened study programmes, and, hinting at the UDN graduates, expressed 'doubts that the Russians provided these students the same training they provide the Soviet students at their best universities' ${ }^{88}$ His doubts were not entirely unfounded. The 1968 report by Egorov and Sofinskii mentioned earlier confirmed the

\footnotetext{
${ }^{80}$ GARF, fond 9606 , op. 1, d. 3529, p. 36, report of 24 June 1968.

${ }^{81}$ TsMAM, fond 3061, op. 1, d. 1406, p. 11, letter to the Rector, 27 June 1969.

${ }^{82}$ GARF, fond 9606, op. 1, d. 3095, p. 47.

${ }^{83}$ TsMAM, fond 3061, op. 1, d. 1406, p. 15, letter to the Rector, 18 March 1969.

${ }^{84}$ GARF, fond 9606 , op. 1, d. 3095, p. 32.

${ }^{85}$ TsMAM, fond 3061, op. 1, d. 1404, p. 65, Report of the Soviet embassy in Tunis, 9 December 1969.

${ }^{86}$ TsMAM, fond 3061, op. 1, d. 1406, p. 14, letter to the Rector, November 1968.

${ }^{87}$ TsMAM, fond 3061, op. 1, d. 1250, p. 51, 'Is Lumumba banned by UNP-FP Gov't?', Forward, 25 April 1968.

${ }^{88} \mathrm{GARF}$, fond 9518 , op. 1 , d. 1112, p. 4.
} 
shortcomings in the training of physicians. The five-year study programme was insufficient, especially for students lacking fundamental knowledge. The report acknowledged that only $12 \%$ had pursued their one-year hospital training. ${ }^{89}$ Whether intentionally or not, however, in the Ghanaian debate the line distinguishing UDN graduates from those of mainstream medical institutes, who had completed a regular programme, was blurred. The negative image of UDN therefore served to disparage Soviet-educated elites altogether. UDN played into the hands of Westerneducated elites, who did not welcome the competition of their Eastern-educated compatriots for prestigious jobs and social capital.

In Latin America too, UDN graduates and especially physicians could face similar problems. Graduates from Mexico and Ecuador reported complications of an administrative nature and delays in accrediting their degrees. A Colombian graduate informed the UDN in September 1971 that her degree had been recognized as a Bachelor's and not as a Master of Sciences. She had, however, secured employment at Magdalena University of Santa Marta. ${ }^{90}$ Some students responded by simply leaving the Communist Party. In 1971, the secretary general of the Brazilian Communist Party, Luís Carlos Prestes, informed the newly appointed UDN rector, Vladimir Stanis, that 'among the graduates there' were 'anti-communists' and others who 'after they returned from the Soviet Union abandoned the Party', adding that 'overall graduates of the Faculty of Engineering work very well'. However, Prestes also noted that 'medical graduates' access to work is more difficult because it was necessary to officially recognize and approve their degrees'. ${ }^{91}$ The same year, according to the Bolivian doctor Héctor Aleman, a senior Communist Party member and alumnus of the Faculty of Medicine, the majority of Bolivian graduates had abandoned the party or converted to Maoism, but had managed to embark on good careers.

Overall, suspicion regarding Moscow's aims and unfavourable comments about the academic level of UND courses were common. Several countries refused to accredit the UDN diploma or did so slowly, and after their commissions had dealt with each returnee separately. An official account of the history of UDN acknowledges the serious difficulties that graduates faced in their careers from the mid 1960s to the 1970s. ${ }^{92}$ Evidence points to an ironic twist: instead of succeeding in its mission to promote socialist-minded elites through positive discrimination, UDN had created a group of disadvantaged specialists - its own graduates.

\section{Reform, heyday, and demise of Lumumba University}

Before the issue of degrees loomed large, such phenomena as indiscipline, long studies at the preparatory faculty, and the dropout rate had sparked concerns. As early as the 1960s measures were taken to raise standards and improve the university's image abroad. On the domestic front, the increase in the ratio of Soviet to foreign students from $1: 10$ to almost $1: 3.5$ by the end of the sixties was meant to help the foreigners learn Russian, ease their integration, and raise the academic level. Another correcting measure consisted in drastically reducing the percentage of enrolees without complete secondary-level education from $26 \%$ at the beginning to $12.8 \%$ in 1962/63 and only $2 \%$ in $1966 / 67$, which in turn allowed the length of studies at the preparatory faculty to be reduced from three to two years beginning in 1964. Nevertheless, even in 1966/67, although in possession of certificates of secondary-level education, every fourth new student was enrolled in the two-year preparatory programme. ${ }^{93}$

\footnotetext{
${ }^{89}$ Egorov and Sofinskii's report, p. 17.

${ }^{90}$ For Bolivia, Mexico, and Colombia, see GARF, fond 9518, op. 1, d. 1584, pp. 8-11; and d. 1406, pp. 16-18, 40. For Ecuador, see Rubinstein, 'Lumumba University', p. 67.

${ }^{91}$ TsMAM, fond 3061 , op. 1, d. 1413, p. 5.

${ }^{92}$ Ponomarenko and Zueva, PFUR and Africa, p. 66.

${ }^{93}$ RGASPI, fond 1, op. 46, d. 294 (for 1962/63); and fond 3, op. 5, d. 132, p. 401 (for 1966/67).
} 
But the biggest and most debated reform consisted of the drastic reduction of specializations from an initial thirty-two to thirteen within a decade. Implemented in two waves, in 1963/64 and $1970 / 71$, this reform was meant to eliminate all specializations considered less relevant to Third World countries, and to concentrate on those that prepared 'specialists of broader profile'. Despite strong reactions by biology professors, who advocated the relevance of their discipline as demonstrated by the exceptionally successful careers of their students, biology was eliminated, as were analytical chemistry, development of oil and gas wells, and industrial planning. At the Faculty of History and Philology, the reform swept away archaeology, ethnography, linguistics, and journalism, maintaining only history and Russian language and literature. Of course, fewer specializations did not necessarily mean the development of curricula that were different from those in mainstream faculties. As the elimination of biology suggests, the criterion for eliminating a specialization was not only its irrelevance. In essence, the reform constituted a pragmatic readjustment of the UDN ambitions in keeping with its resources and the nature of the student body, as well as an effort to forge its academic identity through what the university council believed were meaningful and feasible study programmes. These new programmes remained in force until 1990. The only notable exception was the re-introduction of journalism in 1980, in response to the quest of the Third World for a New International Information Order, which became the most popular specialization at the Faculty of History and Philology. ${ }^{94}$

At the international level, UDN sought to build its legitimacy by adhering to the International Association of Universities in May 1964, sending scholars to international conferences, and, beginning in 1969, hosting the annual UN-sponsored courses for upgrading the qualifications of engineers from 'developing' countries. Bilateral agreements were also signed when political conditions were suitable, as with Sudan in 1965, which became one of the first countries to recognize the UDN degree. The Sudanese dictator, Jaafar Nimeiri, went farther in March 1970, embracing UDN by sponsoring the annual Award of the Democratic Republic of Sudan for the best UDN student. The same year, seizing on the momentum of the Indo-Soviet partnership, Moscow obtained New Delhi's recognition of the UDN degree. ${ }^{95}$

Despite these developments, in most cases the issue of degrees remained unresolved. A UNESCO conference on the equivalence of diplomas held in Moscow in June 1968 brought about no solution. Then, in December 1968, Rumiantsev came up with his own proposal. In a report addressed to the Minister of Education, Vyacheslav Eliutin, he cited the letters of graduates who complained that their qualifications were recognized as a Bachelor's degree but not as a Master's, and identified this as the main problem. His solution combined formal changes and job training, while providing for the further shortening of studies. UDN faculties, he proposed, should first award a Bachelor's degree after completion of the third year, or of the fourth in Medicine, and then the Master's degree one year later. Students should be free to choose if they stopped at the Bachelor level or would go on to pursue graduate studies and gain a Master's degree. In that case, the entire year of the Master's should be devoted to practical training and the writing of a thesis. ${ }^{96}$

Rumiantsev thus endorsed UDN's 'Stakhanovite' concept and advocated its stricter implementation. Countries such as Ethiopia and Laos, impatient to reap the fruits of international aid, subscribed, though with reservations, to the idea of shortened study programmes. But, having weighed the academic arguments and international reactions, Eliutin did not. As a result, Rumiantsev's plan was never implemented. In December 1970, he was replaced by Vladimir Stanis, Eliutin's deputy at the Minvuz, who remained UDN's rector until June 1993. Stanis took office together with instructions to deliver a new reform plan. On 17 July 1971, his plan was sent to Eliutin, with Stanis pushing for a number of major changes. 'It is necessary', he stressed, 'to extend

\footnotetext{
${ }^{94}$ GARF, fond 9606 , op. 9, d. 787, p. 19.

${ }^{95}$ Rubinstein, 'Lumumba University', p. 67.

${ }^{96}$ TsMAM, fond 3061, op. 1, d. 1406, pp. 3-4, Rumiantsev to Eliutin, 23 December 1968.
} 
the duration of studies in all specializations from 6 to 10 months', in order to 'improve the ideological work and the quality of specialists who graduate.' To raise the level, he argued that the ratio of Soviets to foreigners should reach $1: 2$, noting that this increase would in turn reduce the cost of studies per student. Minor changes in the faculty chairs were also proposed in line with the school's policy to train 'specialists of broader profile'. But the most important reform was the extension of study programmes. ${ }^{97}$

With a decree issued on 31 December 1971, the Minvuz ratified Stanis's plan. Beginning in 1972, graduates of the preparatory faculty went on to mainstream departments to study six years at the medical faculty, five years in engineering, natural sciences and mathematics, or in the Russian language and literature programme, and a maximum of four and a half years at the remainder. ${ }^{98}$ This extension came with the reduction of class hours per week and the systematization of practical training for all students. Those studying at the Faculty of History and Philology often underwent training in museums. Mining engineers used the MGU bases in Crimea, and civil engineers worked at construction sites around Moscow, including at the UDN campus. Completed in the mid 1970s, the campus had a polyclinic for the training of medical students, a computer centre, numerous well-equipped laboratories, and many other facilities. As provided by the plan, between 1976 and 1987 the annual enrolment of Soviet students reached an average of 358, against 655 foreigners. ${ }^{99}$ Carefully selected by the Komsomol, they were often PhD candidates who envisioned a career in the burgeoning field of Soviet-Third World relations. Being an international school, which provided linguistic training to its Soviet students, UDN was also the only university in which a Soviet jurist, mathematician, or engineer could defend his thesis in a foreign language.

Stanis took further steps to raise the academic level in line with his proclaimed 'cult of knowledge'. While insisting on class-based affirmative action, he prioritized academic criteria and rejected demands to enrol members of communist parties who did not meet the requirements. 'Unfortunately we cannot admit people without complete secondary-level education', he replied to the request of Luís Carlos Prestes. ${ }^{100}$ In 1972, all enrolees had completed secondary education. UDN graduates who had worked in their countries for at least two years and had remained loyal party members were encouraged to return for a $\mathrm{PhD}$.

The standard political courses taught all over the USSR, such as Marxist-Leninist philosophy or scientific atheism, were also introduced by the end of the sixties. Optional ones included the 'Introduction to the non-capitalist path of development' and the 'Critique of Zionism' to woo Arab students and embassies. 'Improving the ideological work', along with raising the academic standards, had been an argument Stanis had advocated for the extension of study programmes. With regard to academic standards, in 1977 the external state commissions that examined the first cohorts of students who had studied through the new programmes assessed their knowledge positively. The Commission for Marxist-Leninist Philosophy, however, was the only one to stress that the level of 'foreign students was much lower' compared to that of their Soviet counterparts. The issue was passed to the Minvuz, which adopted a resolution criticizing the university and requiring improvements in ideological education. ${ }^{101}$ The incident demonstrates that the school was not fundamentally obsessed with such education.

More important shortcomings persisted, however. Among 3,993 students enrolled from 1976 to 1981 , only 2,913 (73\%) graduated six years later, between 1982 and $1987 .{ }^{102}$ On the other major front, even though the extension of study programmes had removed one obstacle, in many

\footnotetext{
${ }^{97}$ TsMAM, fond 3061, op. 1, d. 1381, pp. 7-23, Stanis to Eliutin, 17 July 1971.

${ }^{98}$ GARF, fond 9606 , op. 1, d. 4527 , pp. 169-75.

${ }^{99}$ GARF, fond 9606, op. 9, d. 787-8.

${ }^{100}$ TsMAM, fond 3061, op. 1, d. 1413, pp. 5-7, Stanis to Luís Carlos Prestes, December 1971.

${ }^{101} \mathrm{GARF}$, fond 9606 , op. 1, d. 8516, p. 25, 8 June 1978.

${ }^{102}$ GARF, fond 9606 , op. 9, d. 787-8.
} 
countries the recognition of the UDN degree remained a vexed question. Algeria, for example, the non-communist country pursuing the most extended educational cooperation with USSR, never accepted UDN scholarships and never recognized its degrees. By contrast, most Sub-Saharan African countries did, and Soviet allies such as Angola, Benin, Congo-Brazzaville, Mali, and Mozambique signed cooperation agreements with UDN. ${ }^{103}$ By 1984, the USSR had signed forty-four bilateral agreements providing for the mutual recognition of degrees. ${ }^{104}$ More foreign governments were now selecting their nationals who studied at UDN. By the end of the 1970s, Nigerian students had returned to UDN. It also became evident that students preferred UDN to mainstream universities in remote Soviet regions.

Economic factors and the international environment played a crucial role in these developments. In the shadow of the 1973 economic crisis, Great Britain introduced 'full-cost' tuition fees for international students coming from countries outside the European Economic Community. ${ }^{105}$ In the US too, tuition fees doubled, whereas the number of scholarships for international students declined. ${ }^{106}$ While one after another Third World countries plunged into recession, oil-producing nations like Nigeria benefited greatly and became major exporters of students to the West, despite the rising costs of education. But the collapse of oil prices in the late 1970s hit the oil-producing countries hard and this, in turn, brought about a decline in the number of their nationals studying in the US and Great Britain. Nigeria, in particular, defaulted on its payments to American universities and cancelled the scholarships paid to Nigerian students abroad. ${ }^{107}$ In the meantime, from 1979 to 1989, the USSR doubled the number of scholarships for African and Arab countries, becoming a top donor of educational aid and a major host country after France and the United States. ${ }^{108}$ Unlike the US, where in $1981 / 82$ only $11.5 \%$ of international students were subsidized, the Soviet Union fully covered the expenses of almost all Third World students. ${ }^{109}$ Against this background, UDN was indeed a showpiece of solidarity and a safe haven.

These developments, however, came late. As recruitment of Third World students all over the USSR gained pace, UDN was no longer their primary destination. Throughout the 1980s, the overwhelming majority studied in the many regular schools such as Kharkov and Kiev state universities, medical and technical institutes, which emerged as major centres for the training of Third World students. As the Togolese political scientist Fafali Koudawo observed - and Table 1 (which shows the evolution of enrolments) corroborates - against the broader picture of Soviet educational aid to the Third World, the much-discussed Lumumba University was 'the tree hiding the forest'. ${ }^{110}$

Lumumba University did not reap the fruits of normalization for long. Under the weight of economic collapse, the Soviet Union fell apart (1989-91), the Soviet-Third World alliance was relegated to the dustbin of history, and Lumumba University no longer had any reason to exist. Fees were introduced and self-financed students were admitted in 1989. In August 1991, Lumumba University signed an agreement with the Commission for the Social and Economic Development of Autonomous Republics and Regions and of Small National Groups of the Russian Federation providing for the training of students, who would navigate the emerging

\footnotetext{
${ }^{103}$ Ponomarenko and Zueva, PFUR and Africa, p. 49.

${ }^{104}$ Fafali Koudawo, La formation des cadres africains en Europe de l'Est depuis 1918: des nègres rouges aux russotiques, Paris: L'Harmattan, 1992, p. 167.

${ }^{105}$ Alice Chandler, Foreign students and government policy: Britain, France and Germany, Washington, DC: American Council on Education, 1985, pp. 1-7.

${ }^{106}$ Philip Coombs, The world crisis in education: the view from the eighties, New York: Oxford University Press, 1985 , p. 321.

${ }^{107}$ Philip Altbach, David H. Kelly, and Y. G.-M. Lulat, Governmental and institutional policies on foreign students: an overview and bibliography, Amherst, NY: State University of New York, 1986, p. 65.

${ }^{108}$ In 1979, there were 11,110 African and 12,191 Arab students in the USSR. In 1989, they were 22,719 and 22,272 respectively. See Katsakioris, 'Creating a socialist intelligentsia'.

${ }^{109}$ Coombs, World crisis in education, p. 321.

${ }^{110}$ Koudawo, La formation des cadres, p. 128.
} 
Table 1. Enrolment of Third World students in all Soviet institutions of tertiary education and in UDN in selected years.

\begin{tabular}{llcccc}
\hline Regions & & 1961 & 1971 & 1980 & 1988 \\
\hline \multirow{2}{*}{ Sub-Saharan Africa } & USSR & 624 & 738 & 2,712 & 4,412 \\
& UDN & 161 & 89 & 173 & 216 \\
& UDN as $\%$ & $25.8 \%$ & $12.1 \%$ & $6.4 \%$ & $4.9 \%$ \\
North Africa and Middle East $^{a}$ & USSR & 760 & 1,030 & 3,500 & 4,703 \\
& UDN & 92 & 180 & 139 & 156 \\
& UDN as $\%$ & $12.1 \%$ & $17.5 \%$ & $4.0 \%$ & $3.3 \%$ \\
Asia $^{b}$ & USSR & 372 & 542 & 1,820 & 2,481 \\
& UDN & 133 & 97 & 98 & 90 \\
& UDN as $\%$ & $35.8 \%$ & $17.9 \%$ & $5.4 \%$ & $3.6 \%$ \\
Latin America $^{c}$ & USSR & 177 & 332 & 1,127 & 1,460 \\
& UDN & 161 & 199 & 222 & 157 \\
Total & UDN as $\%$ & $91.0 \%$ & $60.0 \%$ & $19.7 \%$ & $10.8 \%$ \\
& USSR & 1,933 & 2,642 & 9,159 & 13,056 \\
& UDN & 547 & 565 & 632 & 619 \\
& UDN as $\%$ & $28.3 \%$ & $21.4 \%$ & $6.9 \%$ & $4.7 \%$ \\
\hline
\end{tabular}

${ }^{a}$ Cyprus, Iran, Sudan, and Turkey are included, Israel and Mauritania are not.

bJapan is not included; South Vietnam, Laos and Cambodia are included only in 1961 and 1971, Afghanistan until 1988. 'Without Cuba.

Source: GARF, fond 9606, op. 1, d. 869, 4754, 9121; and fond 9661, op. 1, d. 335.

market economy. ${ }^{111}$ In a sense, the new mission confirmed the university's role in providing the 'right kind' of education for the development of less developed countries through affirmative action. Students from Kalmykia and Ingushetia replaced the subsidized Third World students of the Soviet era; market economics replaced Marxism-Leninism; and racism against people from the Global and post-Soviet South was widespread. On 4 February 1992, Stanis signed a decree allowing foreigners to pay the fees in equipment instead of hard currency. ${ }^{112}$ This was his last decree as rector of Patrice Lumumba University. On 5 February, the university was rechristened the Russian Peoples' Friendship University (RUDN).

Through the painful years of adjustment, by the end of the 2000s, RUDN had capitalized on its infrastructure, experience, and depoliticization, and on the reassertion of Russian power, emerging as the leader in the training of foreign students and a top earner of foreign currency among Russian universities. ${ }^{113}$ By far the most tragic page in its history was written in November 2003, when a fire broke out in a dormitory, taking the lives of forty-two African and Asian students. ${ }^{114}$

\section{Conclusion}

Lumumba was probably the only academic institution targeted by so many diplomatic notes, castigated for its Third World concept, denounced as a school for spies by opponents, or hailed as a symbol of solidarity by proponents. ${ }^{115}$ A common confusion has been to portray it as a successor of the schools of the Communist International which trained cadres and revolutionaries. Confronting these stereotypes, this article has sought to situate UDN in the intellectual and

\footnotetext{
${ }^{111}$ GARF, fond 10026 , op. 4, d. 849 , pp. 1-4.

${ }^{112}$ GARF, fond 10026 , op. 4, d. 849, p. 9.

${ }^{113}$ Alexander Arefiev and Frank Sheregui, Eksport rossiiskikh obrazovatel'nykh uslug: statistitscheskii sbornik (Export of Russian educational services: a statistical survey), Moscow: Ministry of Education and Science, 2014, p. 175.

${ }^{114}$ Jessica Allina-Pisano and Eric Allina-Pisano, "Friendship of peoples" after the fall: violence and pan-African community in post-Soviet Moscow', in Maxim Matusevich, ed., Africa in Russia, Russia in Africa: three centuries of encounters, Trenton, NJ: Africa World Press, 2007, pp. 175-96.

${ }^{115}$ A report of 23 September 1970 from the State Archive of the Security Service of Ukraine (SBU, fond 16, op. 13, d. 1000, p. 223) demonstrates that the KGB approached foreign students to use them as spies. Until now nothing similar has been proved for UDN.
} 
political context at the confluence of decolonization and Cold War. Long-term geopolitical objectives did lie behind its creation, as they lay behind the university for underdeveloped countries which Laugier and Fischer envisioned, and behind the educational aid offered by the US and other countries. The international education policies devised by both capitalist and socialist countries in response to the emergence of the Third World were meant to best serve these objectives. To the benefit of Third World countries, education stood at a strategic intersection of the Cold War battlefield between cultural and development policies. Against this background, educational internationalism was the norm. All Soviet educational education programmes reflected these trends and the importance that Moscow assigned to education for building a Soviet-Third World alliance. Lumumba University was meant to display to the world the superiority of the leading socialist country and to propel friends of the USSR into the elites. It was expected to pay dividends both as an educational institution and as a cultural policy venture.

A sui generis academic institution functioning on ideological premises, Lumumba University had a difficult educational mission. As a consequence, throughout the 1960s, its academic standards were lower compared to mainstream Soviet schools. Even then, however, the efforts of students and professors bore fruit. A 1968 CIA memorandum noted that 'Several graduates of Patrice Lumumba University have been awarded advanced degrees in the United States and Western businessmen who have worked with African graduates of Soviet schools have commented favourably on their performance. ${ }^{\prime 16}$ By a twist of fate, which actually confirms that the training reached high standards, UDN-trained engineers worked in the oil-rich Gulf States and benefited the region's economies. Although the history of returning students remains to be written, notable examples of ministers and heads of state suggest that UDN graduates did become incorporated into the political elites. ${ }^{117}$ In Moscow, among its numerous faculty members, UDN boasted respected professors of geology, biochemistry, and other disciplines, whose textbooks the Minvuz recommended for all students in the USSR, Soviets and foreigners alike. Its new campus and facilities were excellent both by socialist and by international standards. Unlike the curriculum in most Western institutions, the systematic practical training was a major advantage of the Soviet programmes. The reassertion of academic criteria and the extension of study programmes signified that by the 1970s the gap with the mainstream schools had disappeared, and through the development of higher standards UDN had become an almost ordinary Soviet school.

Ironically, this normalization, or retreat from the initial concept, left the university with even fewer educational arguments, if any, to account for its Third World identity. As the admission and education policies changed, questions as to why a Nigerian or Indian student should study mathematics or engineering at UDN and not elsewhere in the USSR could hardly be answered. In medical studies, the emphasis that UDN placed on tropical medicine and diseases was now common at the medical institutes of Kharkov or Crimea, the latter claiming to provide students from the southern hemisphere with the most relevant training. ${ }^{118}$ At the UDN Faculty of History and Philology, students who chose Russian language had few peers who were native speakers. Those who opted for history could attend lectures given by Soviet area specialists, members of the Moscow-based Institutes of Latin America, Africa, and Orientalism. Yet, as the well-known example of Palestinian President Mahmoud Abbas illustrates, scholarship could easily fall victim to politics. ${ }^{119}$ Overall, beyond educational improvements, convincing arguments for the continuing existence of a Third World university were notably absent.

\footnotetext{
${ }^{116}$ Director of Intelligence, 'Assessment of the Soviet program to provide academic training for students from the less developed countries', October 1968, https://www.cia.gov/library/readingroom/docs/DOC_0000326290.pdf (consulted 21 December 2018).

${ }^{117}$ For example, the Namibian President Hifikepunye Pohamba, the Palestinian President Mahmoud Abbas, the President of Guyana Bharrat Jagdeo, and the President of Honduras Porfirio Lobo Sosa.

${ }^{118}$ TsDAVO, fond 4621, op. 13, d. 6282, Report of the Institute's Rector, 1981.

${ }^{119}$ Admitted to UDN, Abbas wrote a PhD thesis entitled, 'The secret relationships between Nazism and Zionism, 1933 1945', which he finally defended at the Institute of Orientalism in 1982.
} 
As a cultural undertaking, therefore, UDN was compromised by its very concept. Third World students and officials were grateful for the scholarships, but never subscribed to the idea of a special university. The Soviets fell into the trap which the French had avoided, thanks to the reactions that Laugier and Fischer encountered in Dakar, Abidjan, and Paris. Regardless of where they were located, special education institutions reminded Africans of the École William Ponty of colonial Senegal. Smaller schools in 'neutral' havens, like the Geneva Centre for the Training of African Experts, founded in 1961 with a grant by the Ford Foundation as a response to UDN, courted African elites more discretely. ${ }^{120}$ But the UDN could not.

As a consequence, to paraphrase William Appleton, Lumumba University became not a 'student trap' but a 'Soviet trap', an expensive liability in Moscow's cultural policy. To make matters worse, the issues linked to the UDN had long-lasting implications. Casting a shadow over the entire Soviet educational assistance to the Third World, its image informed false perceptions about education all over the USSR, and gave the rivals of Soviet-educated elites ammunition by which they could disparage both the Soviet schools and their graduates. As late as 1989, the journal Jeune Afrique could publish misleading articles entitled 'USSR: fast-track training'. ${ }^{121}$ Two years later a Portuguese-educated Guinean claimed that the 'red rag of Patrice Lumumba University' could not compare with his own diploma, and a Togolese scholar could confirm that similar opinions were widespread. ${ }^{122}$ Such views have persisted despite the undeniable educational work carried out by UDN and financed by the Soviet taxpayer.

Constantin Katsakioris is a research fellow at the Bayreuth Academy of Advanced African Studies. He received his PhD from the École des Hautes Études en Sciences Sociales in Paris in 2015 and is currently completing his first monograph, Leçons soviétiques: la formation des étudiants d'Afrique et du Moyen Orient en URSS pendant la guerre froide.

\footnotetext{
${ }^{120}$ Luc Van Dongen, 'Former des élites non communistes pour le tiers-monde: l'Institut Universitaire de Hautes Études Internationales (IUHEI), les États-Unis et la guerre froide', Relations Internationales, 163, 3, 2015, pp. 15-28.

${ }^{121}$ Adama Gaye, 'USSR: fast-track training', Jeune Afrique, 27 November 1989, p. 10.

${ }^{122}$ Koudawo, La formation des cadres, p. 168.
} 